\title{
Efficiency of Aluminium Pillared Montmorillonite Clays of Pakistani Origin (Peshawar And Samwal) on the Adsorption of Chromium Ions in Aqueous Solutions
}

\author{
Nadia Ayub ${ }^{1 *}$, Muhammad Nawaz Chaudhry ${ }^{2}$ \\ ${ }^{1}$ College of Earth and Environmental Sciences, University of the Punjab, Lahore, Pakistan \\ ${ }^{2}$ Department of Environmental Science and Policy, Lahore School of Economics, Pakistan
}

Received: 12 March 2020

Accepted: 27 June 2020

\begin{abstract}
Adsorption of Chromium ions on Aluminium Pillared Interlayered Clays (Al-PILC) prepared from Bentonites originating from Pakistani sources of Peshawar and Samwal was investigated in a batch system. The raw clays were purified and chemically converted into Na-Bentonite. Pillaring procedure was performed on Na-Bentonite with pillaring oligomer solution to prepare Al-PILC. Both Raw and Al-PILC forms of Peshawar and Samwal clays were characterized by X-Ray Diffraction and Brunauer, Emmett, and Teller (BET) analysis before conducting adsorption studies. The effects of factors like adsorbent quantity, the concentration of adsorbate, $\mathrm{pH}$ and temperature were analyzed. Highly efficient adsorption of chromium ions in solution was achieved by Al-PILC. Based on the overall results of percentage removal of chromium ions in solution and in view of efficiency, simplicity, low cost, and reliability, Al-PILCs can provide a promising intervention for the elimination and control of environmental hazards associated with chromium pollution generated from leather industries in Pakistan.
\end{abstract}

Keywords: adsorption, aluminium pillared inter layered clays (Al-PILC), chromium removal, Pakistani bentonite clay, wastewater

\section{Introduction}

Rapid and disorganized urbanization along with dense industrialization in Pakistan has led to severe environmental degradation and exploitation of natural resources [1]. Wastewater generated from various

*e-mail: nadia.ayub85@gmail.com industrial units is usually expelled into surrounding areas damaging ecosystem especially human life [2]. Industrial processes such as metal plating facilities, mining operations, fertilizer industries, tanneries, batteries, paper industries and pesticides produce effluents enriched with heavy metals that are directly or indirectly discharged into the environment. Toxic heavy metals of particular concern in treatment of industrial waste-waters include zinc $(\mathrm{Zn})$, copper $(\mathrm{Cu})$, nickel $(\mathrm{Ni})$, 
mercury $(\mathrm{Hg})$, cadmium $(\mathrm{Cd})$, lead $(\mathrm{Pb})$ and chromium (Cr) [3].

Chromium is released into the environment through several industrial processes like chromium plating, stainless steel manufacturing, wood treatment, paint industry, and tanning industries [4]. Among all these industries, effluent released from tanneries is categorized as a major contributor to chromium pollution [5]. The tannery industry belongs to one of the most polluting industrial sector $[6,7]$. Leather industry has the second largest share in the export sector of Pakistan. It contributes up to 5\% of GDP of the country's economy and provides employment to over 500,000 people [8,9]. Various leather processing units and tanneries have been established throughout the country with over 2500 registered and unregistered tanneries primarily located in two main leather industrial zones: Southern zone representing Sindh and Baluchistan and Northern zone representing Punjab, Khyber Pakhtunkhwa and Azad Jammu and Kashmir. These zones are further divided into numerous tannery clusters with Sialkot having the highest concentration of over 53 units followed by Karachi comprising of more than 44 units [10]. Despite the Leather industry having a substantial economic significance; toxic waste emissions as a result of leather tanning and processing have raised huge environmental concerns. Among the hazardous pollutants, Chromium is abundantly reported in the effluents discharged by leather industries due to excessive use of Chromium Sulphate $\left[\mathrm{Cr}\left(\mathrm{H}_{2} \mathrm{O}\right)_{5}(\mathrm{OH})\right.$ $\mathrm{SO}_{4}$ ] salts [11]. Trivalent chromium ( $\mathrm{Cr}$ (III)) is a major tanning agent used in the leather industry and can have extremely toxic effects on both flora and fauna [12].

Chromium has a tendency to change human physiology. Upon entering food chain, it can result in severe health problems such as skin irritation, ulceration, nasal irritation, eardrum perforation, and lung carcinoma [13]. Ulceration and skin irritation can result due to low-level exposure to chromium. Longterm exposure can affect kidneys and cause liver damage, as well as damage to circulatory and nerve tissue. Chromium accumulates in aquatic organisms, posing threat associated with eating fish that may have been exposed to high levels of the metal [14]. Chromium possesses extreme toxicity which is hazardous to plants, causing the inhabitance of crop growth when the concentration reaches $10 \mathrm{mg} / \mathrm{L}[15,16]$.

Various techniques including reverse osmosis, chemical precipitation, ion exchange and electrolysis have already been developed for the removal of heavy metals from wastewater [17]. Removal of heavy metals from industrial effluents can be achieved through various conventional treatment options, including such unit operations as chemical precipitation, ion exchange, activated carbon adsorption, solvent extraction, coagulation, complexation, foam flotation, cementation, electro-deposition and membrane operations [18]. The limitations for most of the complex processes include high implementation and maintenance cost.
Furthermore, some methods can be inappropriate or ineffective for effluents containing low concentrations of metals [19].

High specific surface area, mechanical and chemical stability, structural properties, ease of access and availability make clay minerals a potentially effective and inexpensive adsorbent [20]. Smectite clays such as montmorillonite have high surface area, cationic exchange capacity and micro and mesoporosity which make them effective and inexpensive adsorbents that are abundantly available [20]. Low cost adsorbent clay minerals such as kaolinite, smectites and zeolites have been utilized to adsorb chromium from waste-waters [21].

Montmorillonite, intercalated and coated by aluminium hydroxides, exhibits much higher adsorption capacity for some heavy metal ions than that of natural montmorillonite [22]. Pillaring process employs intercalation of an expansive by a polyhydroxycation that modifies the physical and chemical properties of clays. This technique enables production of micro and mesoporous materials that are thermally stable while retaining the original lamellar structure of the layered compound [23]. Pillared inter layered clays (PILC) are porous materials that can be utilized in processes of catalysis and adsorption [24]. Owing to easy swelling and high cationic exchange capacity of clays, PILC have gained wide attention due to increased basal spacing and greater specific surface area [25]. Environmental safety and low cost make PILC a promising candidate for use in treatment of wastewater [26]. Inorganic PILCs such as Aluminium Pillared inter layered clays (Al-PILC), Titania-Pillared inter layered clays (TiPILC) and Iron Pillared inter layered clays (Fe-PILC) exhibit higher thermal stability as compared to organic pillared clays [27].

Even though a lot of research work on Bentonite clays and their chemical alteration into pillared clays has been conducted so far; there are very few studies related to pillaring and characterization of pillared bentonites of Pakistani origin. This study provides experimental data on pillaring procedures and intercalation with AlPillars of bentonite clays acquired from two Pakistani sources. It has been studied that these clays have high montmorillonite character with high grade purity and their adsorption capacity can be further enhanced by pillaring process.

Bentonite deposits have been abundantly found at various places in Pakistan. Reasonably big deposits have been found at Attock, Peshawar, Dera Ghazi Khan and Campbellpur, Jhelum, Karak and Mirpur. There are several minor occurrences of bentonite in the whole of Salt Range in Punjab [28].

Bentonite deposit of Peshawar Basin is a part of the fluvial package of Pleistocene to Holocene. This fluvial package consists of cyclic sedimentation comprising of gravel, sandstone and shale/mudstone [29]. This package also contains altered volcanic ashes which now are mostly converted to bentonite clay. 


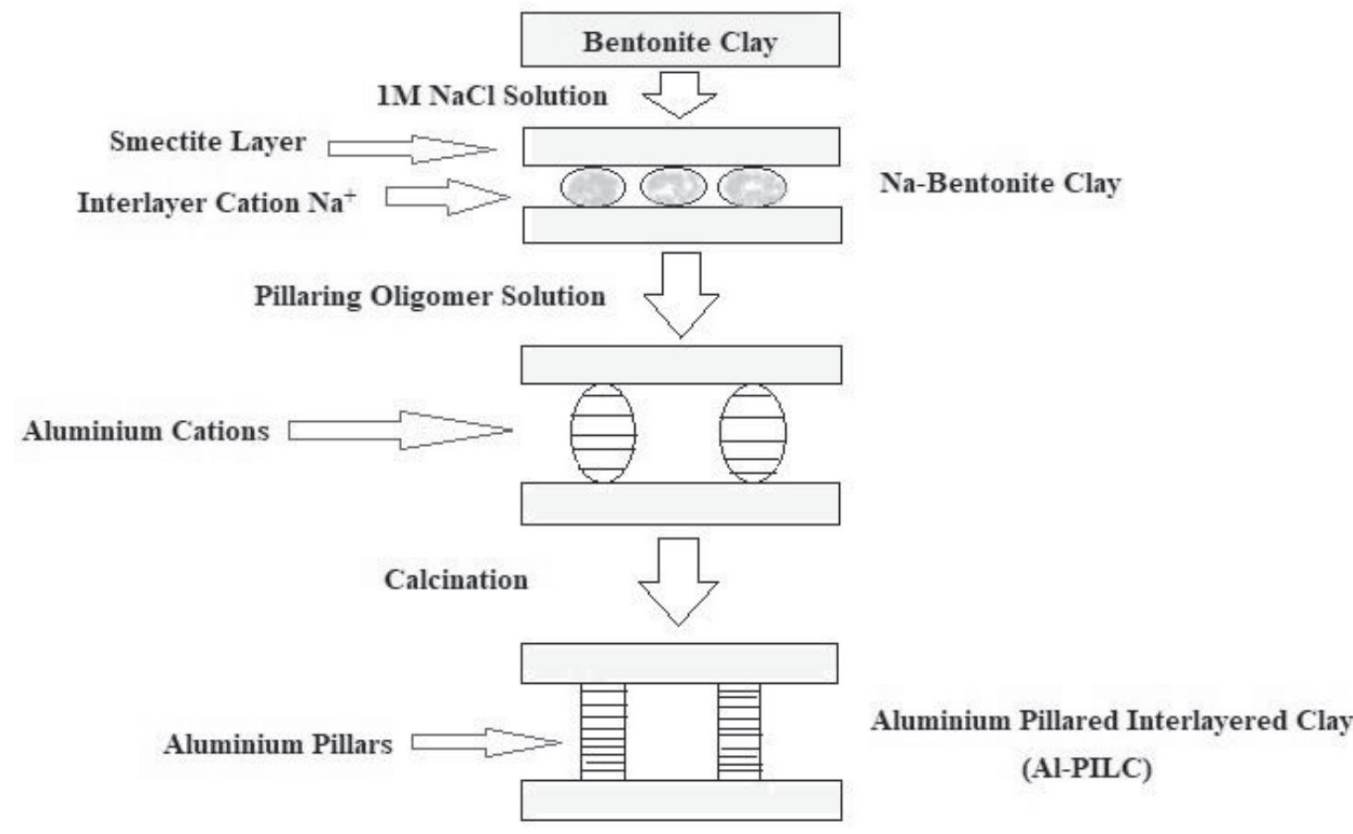

Fig. 1. Schematic illustration for pillaring process carried out to prepare Al-PILC from bentonite clay.

Clay deposit of Samwal occurs within the Siwalik Group of Pliocene Age. The deposits are restricted mainly to the Dhok Pathan Formation of Middle Siwalik. Siwaliks are fluvial deposits laid down by braided river system in a fore deep in front of rising Himalayas after Eocene collision between India and Asia. The deposition is cyclic. During this deposition, volcanic ash was also deposited in the middle Siwalik Dhok Pathan formation which was later converted to fuller's earth (bentonite/Montmorillonite) [29].

Pillaring of clay and using it as an adsorbent for heavy metals is a low cost process; therefore it is suitable and can be easily carried out in industrial establishments in Pakistan. The objective of this research study is to analyze the potential use of Aluminium Inter layered Pillared Clays (Al-PILC) prepared from bentonite clays originating from Pakistan sources of Peshawar and Samwal to adsorb and remove $\mathrm{Cr}$ (III) in solution. Schematic illustration for pillaring process carried out to prepare Al-PILC from bentonite clay is shown in Fig. 1. The adsorption of $\mathrm{Cr}$ (III) on Al-PILC is schematically illustrated as Fig. 2.

\section{Experimental Procedures}

Preparation of Aluminium Pillared Interlayered
Clays (Al-PILC)

$$
\text { Clays (Al-PILC) }
$$

Raw Peshawar and Samwal bentonite clay samples were purified and their $2 \mu \mathrm{m}$ particle size was obtained by sedimentation process [30]. This was followed by treatment with $1 \mathrm{M} \mathrm{NaCl}$ solution to bring clays to their Na-Homoionic form (Na-Bentonite); which acts as precursor for formation of Al-PILC. The resulting NaBentonite clays were washed with deionized water and tested with $\mathrm{AgNO}_{3}$ solution after each wash to ensure complete removal of chloride ions.

Pillaring procedures were then performed on resulting Na-Bentonite clays by following the methodology previously used by researchers [31, 32]. Pillaring oligomer solution was prepared with $\mathrm{Al} / \mathrm{OH}=2\left(0.5 \mathrm{M} \mathrm{AlCl}_{3}\right.$ and $\left.0.2 \mathrm{M} \mathrm{NaOH}\right)$. The mixture was aged for 2 hours at $60^{\circ} \mathrm{C}$ and then kept overnight at room temperature. $25 \% \mathrm{NH}_{4} \mathrm{OH}$ solution was added to increase the $\mathrm{pH}$ of the solution to 6 . This oligomer solution was added dropwise to an aqueous

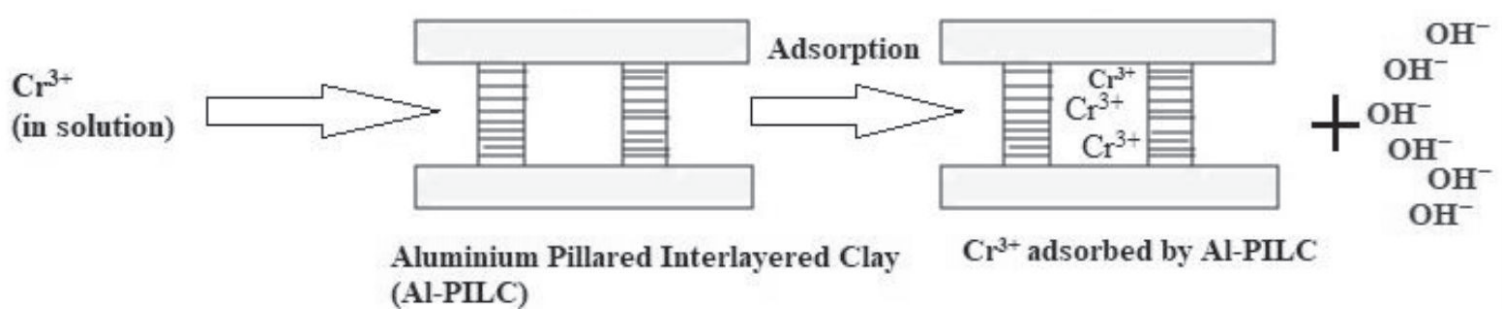

Fig. 2. Schematic illustration for adsorption of Cr (III) on Al-PILC. 
clay suspension (1:1 previously stirred overnight at room temperature) at $80^{\circ} \mathrm{C}$ under continuous stirring for 3 hours. The suspension was then kept overnight at room temperature. This was followed by washing of suspension by centrifuge to remove conflicting chloride ions (tested by $\mathrm{AgNO}_{3}$ ). Washed and chloride free clay suspension was then freeze dried and calcined under a flow of dried air at $400^{\circ} \mathrm{C}$ for $2-4$ hours.

\section{Characterization of Raw and Al-PILC Samples}

Characterization studies using analytical techniques of X-Ray Diffraction and Brunauer, Emmett, and Teller (BET) analysis were conducted for both Peshawar and Samwal clays to determine the changes occurring in the structural and mineralogical aspects of untreated and chemically modified Al-PILCs. X-RD patterns were obtained by PANalytical XPert PRO Version using $\mathrm{Cu}$ K- $\alpha$ Radiation. Surface area and porosity were measured by BET analysis on Micromeritics - Tristar II equipment.

\section{Adsorption Experiments}

Adsorption studies for Chromium metal ions using Peshawar and Samwal raw and Al-Pillared clays were carried out by batch adsorption experimental procedures. Calculated amounts of $\mathrm{Cr}\left(\mathrm{NO}_{3}\right)_{3}$ were dissolved in distilled water to prepare its $1000 \mathrm{ppm}$ stock solution. This was further diluted to prepare standard solutions with concentrations $10 \mathrm{ppm}$, $20 \mathrm{ppm}, 50 \mathrm{ppm}$ and $100 \mathrm{ppm}$. Different batch adsorption experiments were conducted by varying weight of adsorbent used, concentration of standard solutions, temperature and $\mathrm{pH}$ of solutions. In all experiments for each clay one parameter was varied while others were kept constant to achieve optimum adsorption of $\mathrm{Cr}$ (III) under variable conditions.

\section{Varying Weight of Adsorbent}

Five different weights: $0.5 \mathrm{~g}, 1 \mathrm{~g}, 1.5 \mathrm{~g}, 2 \mathrm{~g}$ and $2.5 \mathrm{~g}$ of Peshawar and Samwal clay samples (raw and Al-PILC) were separately taken in different plastic bottles. $50 \mathrm{ml}$ of $100 \mathrm{ppm}$ standard solution was poured into each bottle and stirred for an hour on orbital shaker. The mixture was then filtered and concentration of the supernatant liquid was determined by Inductively Coupled Plasma Atomic Emission Spectroscopy (ICPAES).

\section{Varying Concentration of the Standard Solutions}

$50 \mathrm{ml}$ of all four different standard solutions: $10 \mathrm{ppm}, 20 \mathrm{ppm}, 50 \mathrm{ppm}$ and $100 \mathrm{ppm}$ were poured into separate plastic bottles. 0.5 grams of each clay sample was added to these bottles and stirred for an hour on an orbital shaker followed by filtration. ICP-AES was used to calculate the concentration of resulting supernatant liquids.

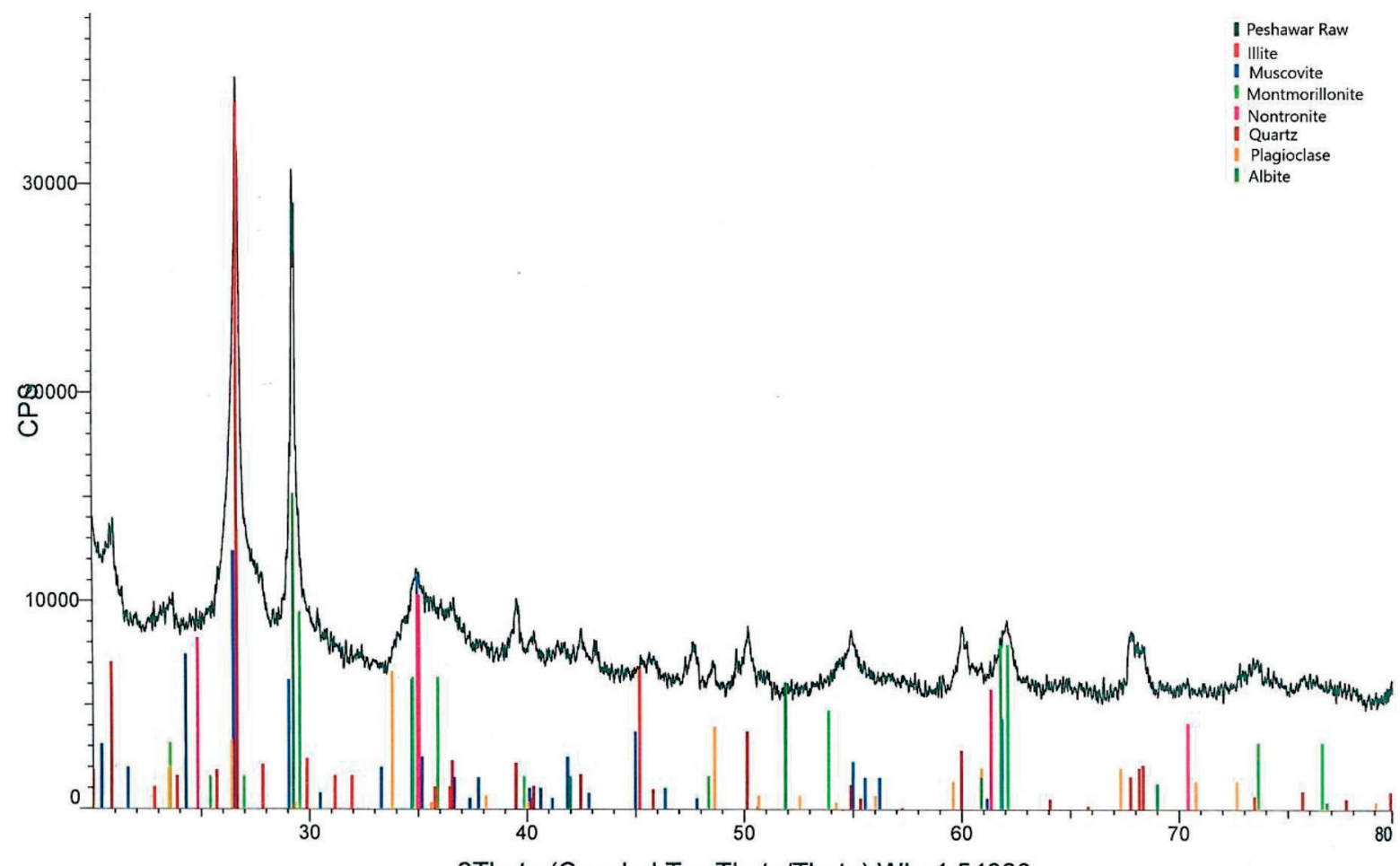

Fig. 3. X-Ray Diffractogram Peshawar Raw Clay. 


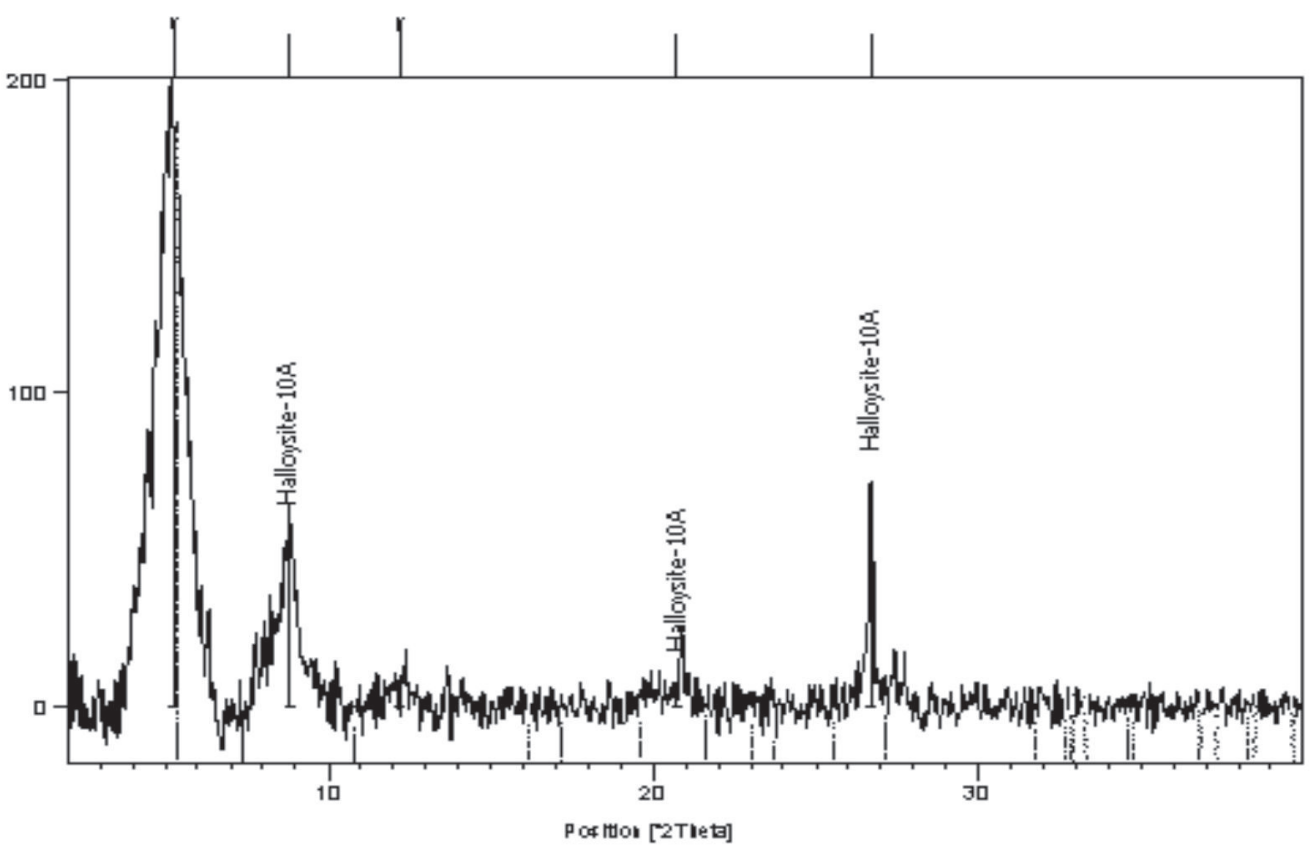

Fig. 4. X-Ray Diffractogram for Peshawar Al-PILC.

\section{Varying $\mathrm{pH}$}

$0.5 \mathrm{~g}$ of each clay sample, along with $50 \mathrm{ml}$ of $100 \mathrm{ppm}$ standard solution, were taken in 2 separate beakers. $2 \mathrm{ml}$ of I $\mathrm{N} \mathrm{HCl}$ was added to the solution in one beaker and $2 \mathrm{ml}$ of I $\mathrm{N} \mathrm{NaOH}$ to the other one. The contents of the beakers were stirred for an hour and then filtered. The concentration of the metal in solution was determined by ICP-AES.

\section{Varying Temperature}

$0.5 \mathrm{~g}$ of clay sample and $50 \mathrm{ml}$ of $100 \mathrm{ppm}$ standard solution were taken in a beaker. The mixture was stirred and kept at varying temperatures $\left(35-75^{\circ} \mathrm{C}\right)$ for one hour. The solutions were then filtered and the concentration was analyzed by ICP-AES.

\section{Results and Discussion}

\section{Characterization Studies}

Both Peshawar and Samwal clays were subjected to X-Ray diffraction analysis and are presented as Fig 3. and Fig 5. respectively. These diffractograms show that the Peshawar Raw clay contains Nontronite and Montmorillonite, which belong to the Smectite group and are the predominant phase. The other minerals present are Muscovite, Illite, Quartz and Plagioclase. The Samwal raw sample contains bentonitic clays with Montmorillonite and Nontronite as the predominant phase whereas the other phases present are Illite, Muscovite, Sodium Sulphate, Quartz and Plagioclase.
X-Ray diffractograms for both Peshawar and Samwal AL-PILC samples show obvious inclusion of Al pillars between layers within the structure of clay. This indicates significant addition of Al cations. It is further confirmed by the variations in basal (d) spacing of raw clay and Al-PILC samples. The basal spacing in Peshawar Al-PILC (Fig. 4) has remarkably increased from to $3.3589 \mathrm{~A}^{\circ}$ (raw sample) to $16.8261 \mathrm{~A}^{\circ}$. The basal spacing for Samwal Al-PILC, as shown in Fig. 6, also expanded to $15.4191 \mathrm{~A}^{\circ}$ from $4.4642 \mathrm{~A}^{\circ}$ (raw sample).

The Brunauer, Emmett, and Teller (BET) Analysis (Table 1) shows a significant increase in surface area $\left(\mathrm{S}_{\mathrm{BET}}\right)$ and pore volume $\left(\mathrm{V}_{\text {TOTAL }}\right)$ for both Peshawar and Samwal Al-PILCs as compared to their raw variants. Significant increase in surface area is observed for Peshawar Al-PILC i.e. $58.50 \mathrm{~m}^{2} / \mathrm{g}$ from $14.17 \mathrm{~m}^{2} / \mathrm{g}$. It is accompanied by massive increase in pore volume and decrease in pore size (a difference of $0.040 \mathrm{~cm}^{3} / \mathrm{g}$ and $8 \mathrm{~A}^{\circ}$ respectively). The X-RD result for Peshawar Al-PILC supports its BET analysis for enormous increase in surface area and pore volume. Similarly, Samwal Al-PILC has an enhanced surface area of $44.22 \mathrm{~m}^{2} / \mathrm{g}$ from $34.36 \mathrm{~m}^{2} / \mathrm{g}$ found in the raw variant. Simultaneously, there is a decrease in the pore size and increase in the pore volume.

\section{Batch Adsorption Studies}

\section{Effect on Adsorption by Varying Weight of Adsorbent}

Results for adsorption study of $\mathrm{Cr}$ (III) in solution by varying weight of adsorbent using raw and AlPILC forms of Peshawar clay are shown in Table 2. Adsorption increases with the amount of adsorbent used 


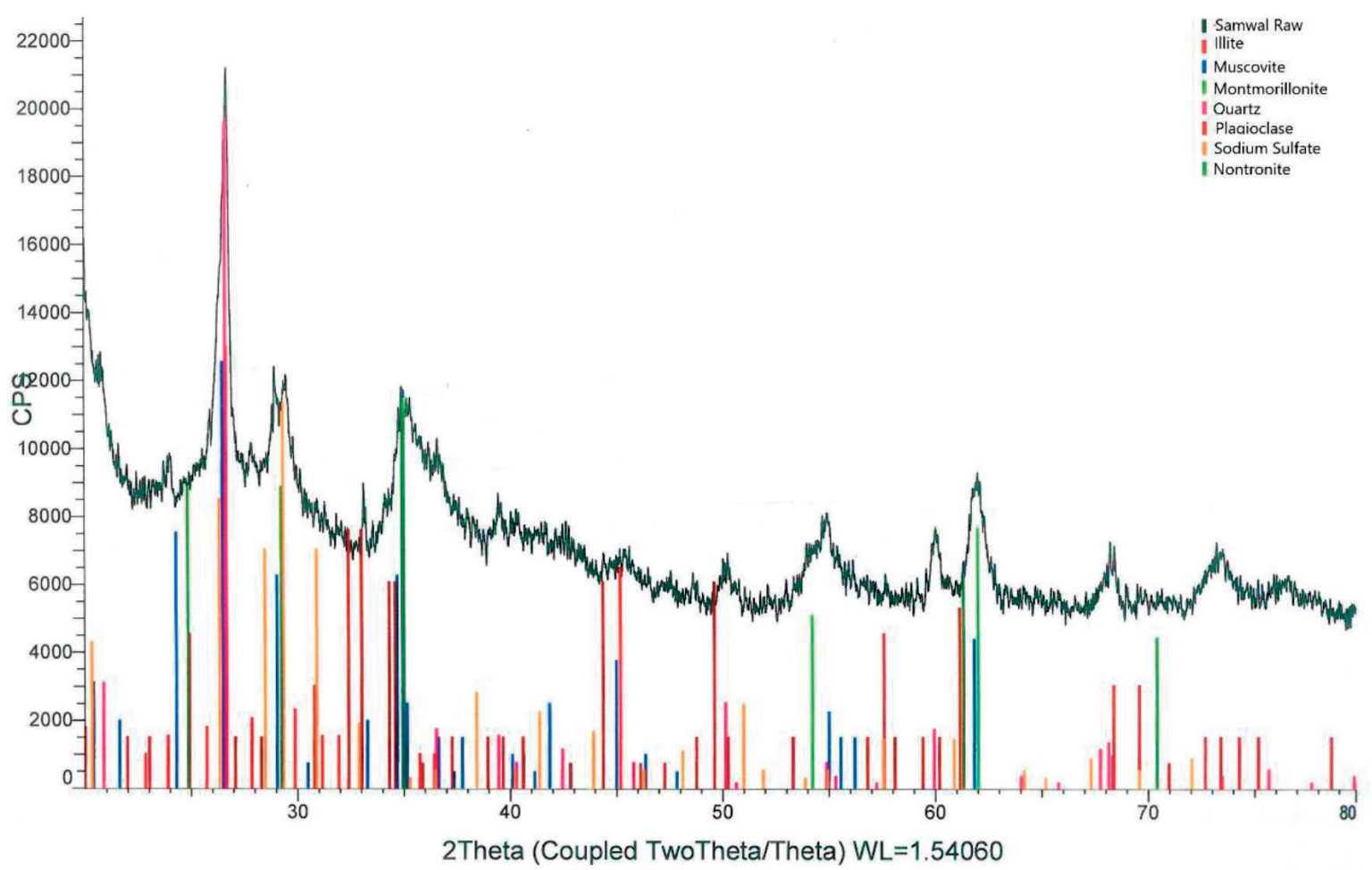

Fig. 5. X-Ray Diffractogram for Samwal Raw Clay.

Table 1. Brunauer, Emmett, and Teller (BET) Analysis for surface area and pore-size distribution for Peshawar and Samwal: Raw clay, Na-Bentonite and Al-PILC.

\begin{tabular}{|c|c|c|c|}
\hline & $\begin{array}{c}\text { Surface Area } \\
/ \mathrm{m}^{2} \mathrm{~g}^{-1}\end{array}$ & $\begin{array}{c}\text { Pore Volume } \\
/ \mathrm{cm}^{3} \mathrm{~g}^{-1}\end{array}$ & $\begin{array}{c}\text { Pore Size } \\
/ \mathrm{A}^{\circ}\end{array}$ \\
\hline Peshawar Raw Clay & 14.17 & 0.017 & 37.48 \\
\hline Peshawar - Na-Bentonite & 39.95 & 0.034 & 34.58 \\
\hline Peshawar Al-PILC & 58.50 & 0.057 & 39.46 \\
\hline Samwal Raw Clay & 34.36 & 0.034 & 33.44 \\
\hline Samwal Na-Bentonite & 42.86 & 0.035 & 38.36 \\
\hline Samwal Al-PILC & 44.22 & 0.042 & \\
\hline
\end{tabular}

Table 2. Effect on Adsorption of Cr (III) by varying weight of Peshawar Raw and Al-PILC.

\begin{tabular}{|c|c|c|c|c|c|c|c|c|}
\hline \multirow[b]{2}{*}{$\begin{array}{c}\mathrm{Sr} \\
\text { No. }\end{array}$} & \multirow[b]{2}{*}{$\begin{array}{l}\text { Weight of } \\
\text { adsorbent } \\
\quad / g\end{array}$} & \multirow[b]{2}{*}{$\begin{array}{c}\text { Initial } \\
\text { concentration } \\
\text { /PPM }\end{array}$} & \multicolumn{3}{|c|}{ PESHAWAR - RAW } & \multicolumn{3}{|c|}{ PESHAWAR Al-PILC } \\
\hline & & & $\begin{array}{c}\text { Final } \\
\text { concentration } \\
\text { /PPM }\end{array}$ & $\begin{array}{c}\text { Percentage } \\
\text { adsorption } \\
\quad / \%\end{array}$ & $\begin{array}{c}\text { Amount } \\
\text { of metal } \\
\text { adsorbed } \\
/ \mathrm{mg} / \mathrm{g}\end{array}$ & $\begin{array}{c}\text { Final } \\
\text { concentration } \\
\text { /PPM }\end{array}$ & $\begin{array}{c}\text { Percentage } \\
\text { adsorption } \\
\quad / \%\end{array}$ & $\begin{array}{c}\text { Amount } \\
\text { of metal } \\
\text { adsorbed } \\
/ \mathrm{mg} / \mathrm{g}\end{array}$ \\
\hline 1 & 0.5 & 100 & 17.3 & 82.7 & 8.27 & 0 & 100 & 10 \\
\hline 2 & 1 & 100 & 12.5 & 87.5 & 4.38 & 0 & 100 & 5.0 \\
\hline 3 & 1.5 & 100 & 10.3 & 89.7 & 2.99 & 0 & 100 & 3.3 \\
\hline 4 & 2 & 100 & 11.0 & 89.0 & 2.23 & 0 & 100 & 2.5 \\
\hline 5 & 2.5 & 100 & 9.7 & 90.3 & 1.81 & 0 & 100 & 2 \\
\hline
\end{tabular}


Table 3. Effect on Adsorption of Cr (III) by varying weight of Samwal Raw and Al-PILC.

\begin{tabular}{|c|c|c|c|c|c|c|c|c|}
\hline & & & \multicolumn{3}{|c|}{ SAMWAL-RAW } & \multicolumn{3}{|c|}{ SAMWAL Al-PILC } \\
\cline { 4 - 9 } $\begin{array}{c}\text { Sr } \\
\text { No. }\end{array}$ & $\begin{array}{c}\text { Weight of } \\
\text { adsorbent } \\
/ \mathrm{g}\end{array}$ & $\begin{array}{c}\text { Initial } \\
\text { concentration } \\
/ \mathrm{PPM}\end{array}$ & $\begin{array}{c}\text { Final } \\
\text { concentration } \\
/ \mathrm{PPM}\end{array}$ & $\begin{array}{c}\text { Percentage } \\
\text { adsorption } \\
/ \%\end{array}$ & $\begin{array}{c}\text { Amount } \\
\text { of metal } \\
\text { adsorbed } \\
/ \mathrm{mg} / \mathrm{g}\end{array}$ & $\begin{array}{c}\text { Final } \\
\text { concentration } \\
/ \mathrm{PPM}\end{array}$ & $\begin{array}{c}\text { Percentage } \\
\text { adsorption } \\
/ \%\end{array}$ & $\begin{array}{c}\text { Amount } \\
\text { of metal } \\
\text { adsorbed } \\
/ \mathrm{mg} / \mathrm{g}\end{array}$ \\
\hline 1 & 0.5 & 100 & 17.3 & 82.7 & 8.27 & 0 & 100 & 10 \\
\hline 2 & 1 & 100 & 12.5 & 87.5 & 4.38 & 0 & 100 & 5.0 \\
\hline 3 & 1.5 & 100 & 10.3 & 89.7 & 2.99 & 0 & 100 & 3.3 \\
\hline 4 & 2 & 100 & 11.0 & 89.0 & 2.23 & 0 & 100 & 2.5 \\
\hline 5 & 2.5 & 100 & 9.7 & 90.3 & 1.81 & 0 & 100 & 2 \\
\hline
\end{tabular}

( $82.7 \%$ with $0.5 \mathrm{~g}$ rising up to $90.3 \%$ with the maximum amount of clay i.e $2.5 \mathrm{~g}$ ). Peshawar Al-PILC completely eliminates $\mathrm{Cr}$ (III) even with the least amounts of adsorbent used.

Table 3 shows adsorption results for $\mathrm{Cr}$ (III) in solution by varying weight of Samwal raw and Al-PILC. The raw variant adsorbs considerably lower amounts of $\mathrm{Cr}$ (III) as compared to the pillared variant. The minimum amount of Cr (III) adsorbed by Samwal raw clay is $70.9 \%$ with $0.5 \mathrm{~g}$ of clay and a maximum of $82.9 \%$ with 2.5 g clay. In comparison, Samwal Al-PILC removes $98 \%$ of $\mathrm{Cr}$ (III) with the least amount of clay $(0.5 \mathrm{~g})$ and then shows significantly complete adsorption with slight increase in weight at $1 \mathrm{~g}$.

The comparative graphical study of effect on adsorption by varying weight of adsorbent for $\mathrm{Cr}$ (III) in solution by both Peshawar and Samwal's Raw and Al-PILC variants are shown in Fig. 7.

\section{Effect on Adsorption by Varying Concentration of Solution}

Results for adsorption of $\mathrm{Cr}$ (III) by varying concentration of solution by Peshawar and Samwal's raw clay and Al-PILC are shown Fig. 8. The effect on adsorption of $\mathrm{Cr}$ (III) by varying concentration of solution by Peshawar Raw clay and Al-PILC is shown in Table 4. Complete adsorption of $\mathrm{Cr}$ (III) at all concentrations of solution takes place by Peshawar Al-PILC. This makes it a highly favourable adsorbent for removal of the metal ion from wastewaters with elevated level of chromium. Comparatively moderate amounts of Cr (III) are adsorbed by Raw Peshawar clay.

Table 5 shows results for effect on adsorption of $\mathrm{Cr}$ (III) by varying the concentration of solution for raw and pillared forms of Samwal Clay. Samwal Al-PILC completely adsorbed $\mathrm{Cr}$ (III) present in all

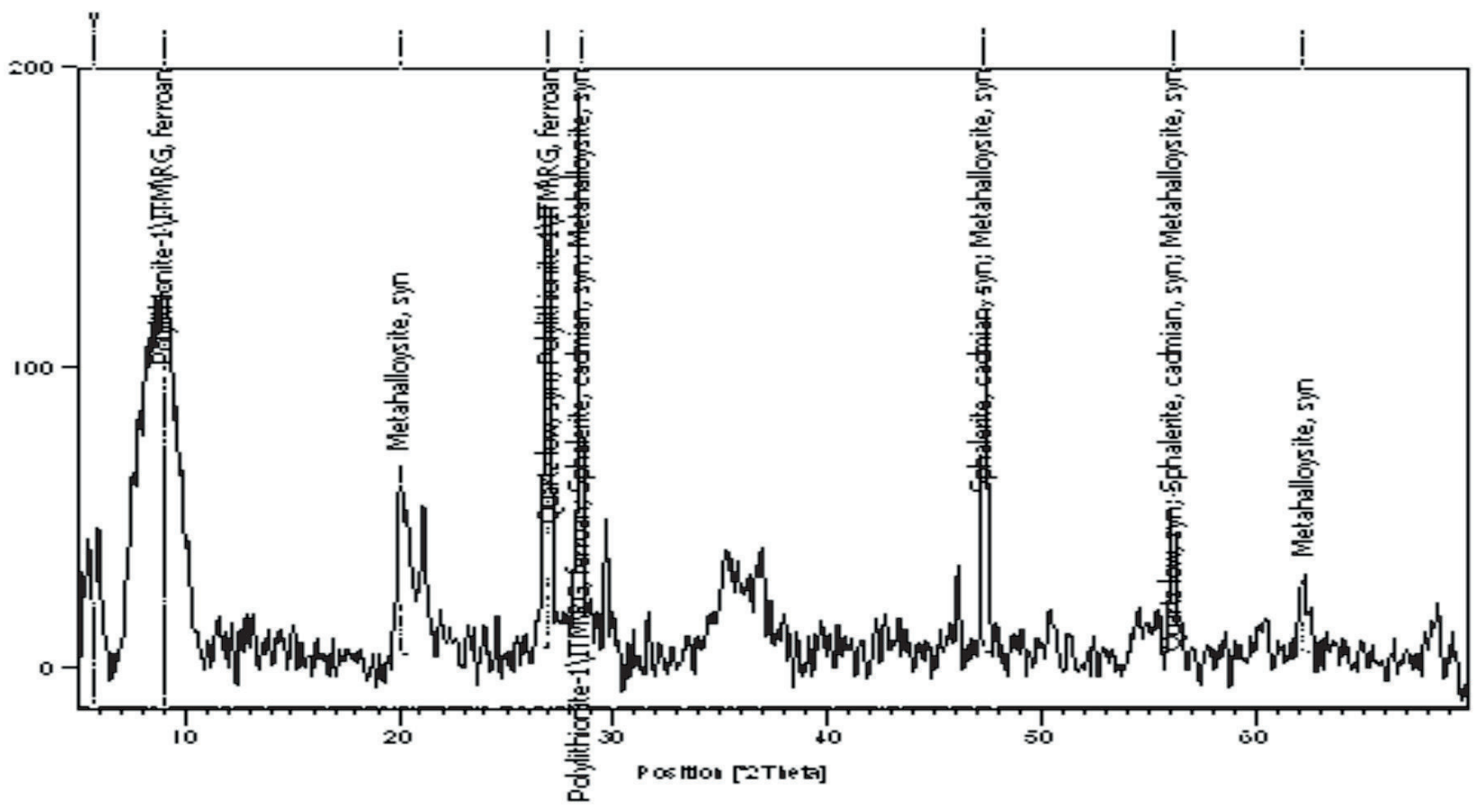

Fig. 6. X-Ray Diffractogram for Samwal A-PILC. 

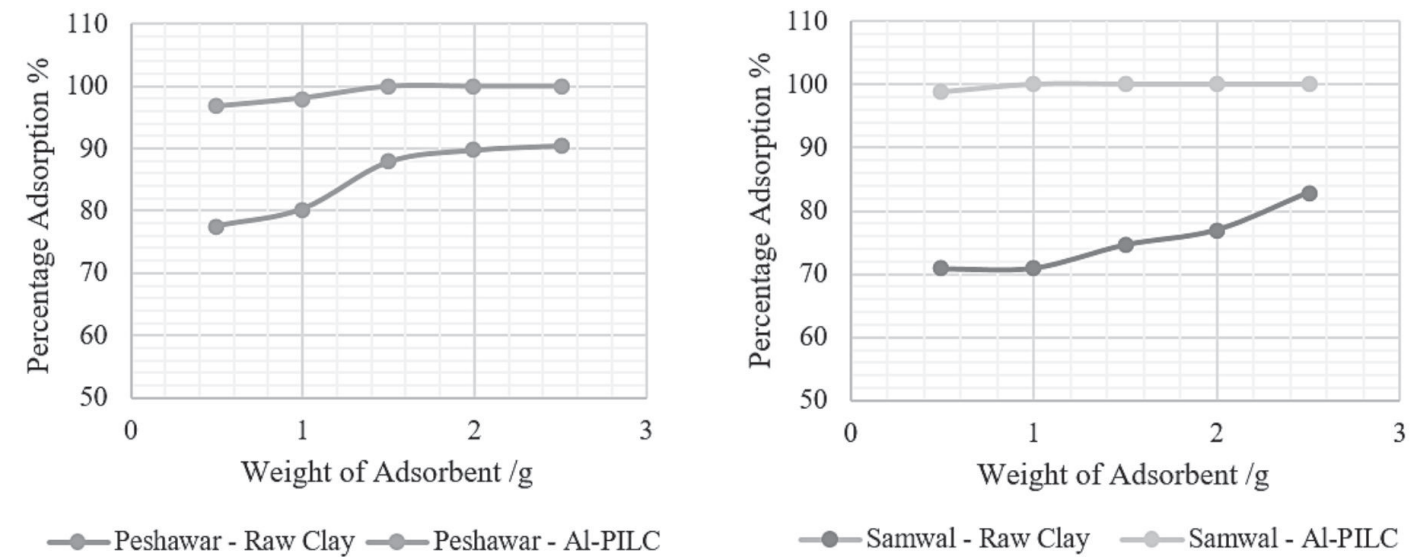

Fig. 7. Effect on Adsorption of Cr (III) by varying Weight of Adsorbent: Peshawar Raw \& Al-PILC and Samwal Raw \& Al-PILC.
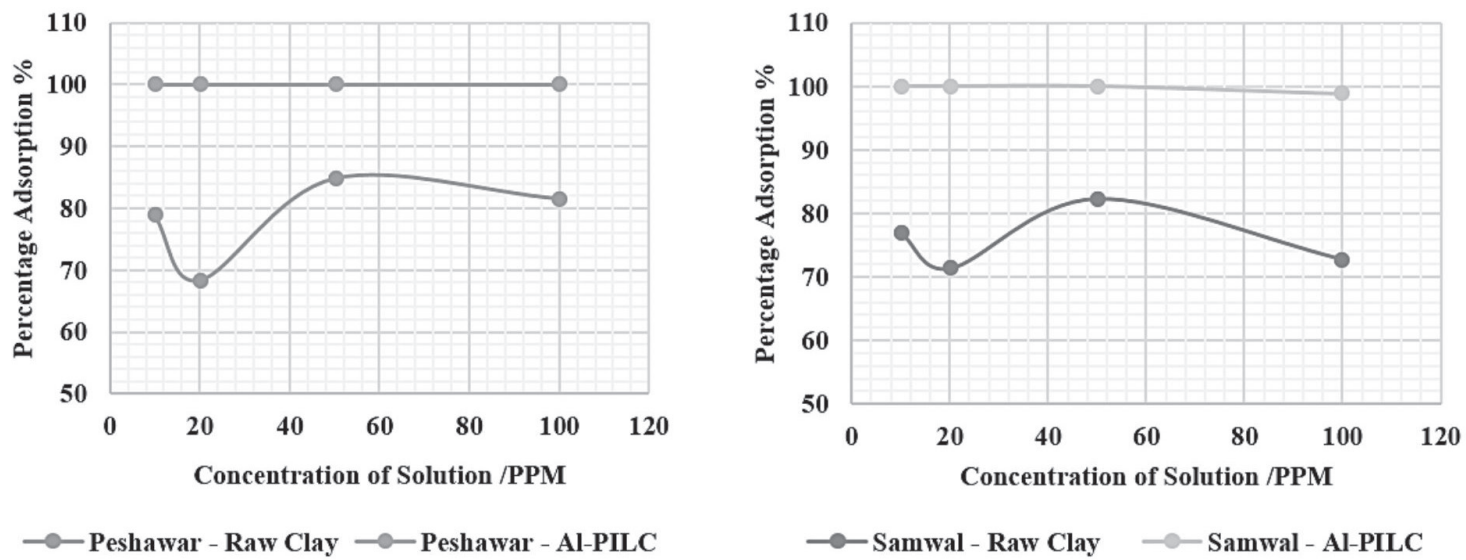

Fig. 8. Effect on Adsorption of Cr (III) by varying Concentration of Solution: Peshawar Raw \& Al-PILC and Samwal Raw \& Al-PILC.

concentrations. Significantly poor adsorption results are seen for the raw sample of Samwal clay, with highest amounts of $\mathrm{Cr}$ (III) (82.2\%) adsorbed at $50 \mathrm{PPM}$ and the least $(71.4 \%)$ at 20 PPM.

\section{Effect on Adsorption by Varying pH of Solution}

The $\mathrm{pH}$ of these solution not only determines the degree of speciation and ionization of $\mathrm{Cr}$ but also affects the surface charge of modified clay $[33,34]$. The results for effect on adsorption of $\mathrm{Cr}$ (III) by varying $\mathrm{pH}$ of solution for Peshawar raw clay and Al-PILC are presented in Table 6 . The raw clay sample adsorbs only $84.7 \%$ of $\mathrm{Cr}$ (III) at acidic condition ( $\mathrm{pH} 5$ ) and its adsorption capacity further decreases to $76.6 \%$ at alkaline conditions ( $\mathrm{pH}$ 9). The Pillared sample of Peshawar clay shows complete adsorption at both neutral and acidic $\mathrm{pH}$, hence making it a highly suitable candidate for adsorption of Cr (III) in acidic effluents. However, the adsorption efficiency decreases to $90.3 \%$

Table 4. Effect on Adsorption of Cr (III) by varying Concentration of Solution: Peshawar Raw and Al-PILC

\begin{tabular}{|c|c|c|c|c|c|c|c|c|}
\hline & & & \multicolumn{3}{|c|}{ PESHAWAR - RAW } & \multicolumn{3}{c|}{ PESHAWAR Al-PILC } \\
\cline { 4 - 9 } $\mathrm{Sr}$ & $\begin{array}{c}\text { Weight of } \\
\text { adsorbent } \\
/ \mathrm{g}\end{array}$ & $\begin{array}{c}\text { Initial } \\
\text { concentration } \\
/ \mathrm{PPM}\end{array}$ & $\begin{array}{c}\text { Final } \\
\text { concentration } \\
/ \mathrm{PPM}\end{array}$ & $\begin{array}{c}\text { Percentage } \\
\text { adsorption } \\
/ \%\end{array}$ & $\begin{array}{c}\text { Amount } \\
\text { of metal } \\
\text { adsorbed } \\
/ \mathrm{mg} / \mathrm{g}\end{array}$ & $\begin{array}{c}\text { Final } \\
\text { concentration } \\
/ \mathrm{PPM}\end{array}$ & $\begin{array}{c}\text { Percentage } \\
\text { adsorption } \\
/ \%\end{array}$ & $\begin{array}{c}\text { Amount } \\
\text { of metal } \\
\text { adsorbed } \\
/ \mathrm{mg} / \mathrm{g}\end{array}$ \\
\hline 1 & 0.5 & 10 & 2.12 & 78.8 & 0.79 & 0 & 100 & 1.00 \\
\hline 2 & 0.5 & 20 & 6.32 & 68.4 & 1.34 & 0 & 100 & 2.00 \\
\hline 3 & 0.5 & 50 & 7.51 & 84.9 & 4.25 & 0 & 100 & 5.00 \\
\hline 4 & 0.5 & 100 & 18.4 & 81.6 & 8.16 & 0 & 100 & 10.0 \\
\hline
\end{tabular}


Table 5. Effect on Adsorption of Cr (III) by varying Concentration of Solution: Samwal Raw and Al-PILC.

\begin{tabular}{|c|c|c|c|c|c|c|c|c|}
\hline & & & \multicolumn{3}{|c|}{ SAMWAL-RAW } & \multicolumn{3}{c|}{ SAMWAL Al-PILC } \\
\cline { 5 - 10 } $\begin{array}{c}\text { Sr } \\
\text { No. }\end{array}$ & $\begin{array}{c}\text { Weight of } \\
\text { Adsorbent } \\
/ \mathrm{g}\end{array}$ & $\begin{array}{c}\text { Initial } \\
\text { concentration } \\
/ \mathrm{PPM}\end{array}$ & $\begin{array}{c}\text { Final } \\
\text { concentration } \\
/ \mathrm{PPM}\end{array}$ & $\begin{array}{c}\text { Percentage } \\
\text { adsorption } \\
/ \%\end{array}$ & $\begin{array}{c}\text { Amount } \\
\text { of metal } \\
\text { adsorbed } \\
/ \mathrm{mg} / \mathrm{g}\end{array}$ & $\begin{array}{c}\text { Final } \\
\text { concentration } \\
/ \mathrm{PPM}\end{array}$ & $\begin{array}{c}\text { Percentage } \\
\text { adsorption } \\
/ \%\end{array}$ & $\begin{array}{c}\text { Amount } \\
\text { of metal } \\
\text { adsorbed } \\
/ \mathrm{mg} / \mathrm{g}\end{array}$ \\
\hline 1 & 0.5 & 10 & 2.31 & 76.9 & 0.77 & 0 & 100 & 1.00 \\
\hline 2 & 0.5 & 20 & 5.73 & 71.4 & 1.43 & 0 & 100 & 2.00 \\
\hline 3 & 0.5 & 50 & 8.91 & 82.2 & 4.11 & 0 & 100 & 5.00 \\
\hline 4 & 0.5 & 100 & 27.2 & 72.8 & 7.23 & 1.02 & 98.9 & 9.89 \\
\hline
\end{tabular}

Table 6. Effect on Adsorption of Cr (III) by varying pH of solution: Peshawar Raw and Al-PILC.

\begin{tabular}{|c|c|c|c|c|c|c|c|c|c|}
\hline & & & & \multicolumn{3}{|c|}{ PESHAWAR - RAW } & \multicolumn{3}{|c|}{ PESHAWAR Al-PILC } \\
\cline { 5 - 10 } $\begin{array}{c}\mathrm{Sr} \\
\text { No. }\end{array}$ & $\mathrm{pH}$ & $\begin{array}{c}\text { Weight of } \\
\text { adsorbent } \\
/ \mathrm{g}\end{array}$ & $\begin{array}{c}\text { Initial } \\
\text { concentration } \\
/ \mathrm{PPM}\end{array}$ & $\begin{array}{c}\text { Final } \\
\text { concentration } \\
/ \mathrm{PPM}\end{array}$ & $\begin{array}{c}\text { Percentage } \\
\text { adsorption } \\
/ \%\end{array}$ & $\begin{array}{c}\text { Amount } \\
\text { of metal ad- } \\
\text { sorbed } \\
/ \mathrm{mg} / \mathrm{g}\end{array}$ & $\begin{array}{c}\text { Final } \\
\text { concentration } \\
/ \mathrm{PPM}\end{array}$ & $\begin{array}{c}\text { Percentage } \\
\text { adsorption } \\
/ \%\end{array}$ & $\begin{array}{c}\text { Amount } \\
\text { of metal } \\
\text { adsorbed } \\
/ \mathrm{mg} / \mathrm{g}\end{array}$ \\
\hline 1 & 5 & 0.5 & 10 & 15.3 & 84.7 & 8.47 & 0 & 100 & 10.0 \\
\hline 2 & 7 & 0.5 & 20 & 18.1 & 81.9 & 8.19 & 0 & 100 & 10.0 \\
\hline 3 & 9 & 0.5 & 50 & 23.4 & 76.6 & 7.66 & 9.7 & 90.3 & 9.03 \\
\hline
\end{tabular}

Table 7. Effect on Adsorption of Cr (III) by varying pH of solution: Samwal Raw and Al-PILC.

\begin{tabular}{|c|c|c|c|c|c|c|c|c|c|}
\hline & & & & \multicolumn{3}{|c|}{ SAMWAL-RAW } & \multicolumn{3}{|c|}{ SAMWAL Al-PILC } \\
\cline { 5 - 10 } $\begin{array}{c}\text { Nr } \\
\text { No. }\end{array}$ & $\mathrm{pH}$ & $\begin{array}{c}\text { Weight of } \\
\text { adsorbent } \\
/ \mathrm{g}\end{array}$ & $\begin{array}{c}\text { Initial } \\
\text { concentration } \\
/ \mathrm{PPM}\end{array}$ & $\begin{array}{c}\text { Final } \\
\text { concentration } \\
/ \mathrm{PPM}\end{array}$ & $\begin{array}{c}\text { Percentage } \\
\text { adsorption } \\
/ \%\end{array}$ & $\begin{array}{c}\text { Amount of } \\
\text { metal } \\
\text { adsorbed } \\
/ \mathrm{mg} / \mathrm{g}\end{array}$ & $\begin{array}{c}\text { Final } \\
\text { concentration } \\
/ \mathrm{PPM}\end{array}$ & $\begin{array}{c}\text { Percentage } \\
\text { adsorption } \\
/ \%\end{array}$ & $\begin{array}{c}\text { Amount of } \\
\text { metal } \\
\text { adsorbed } \\
/ \mathrm{mg} / \mathrm{g}\end{array}$ \\
\hline 1 & 5 & 0.5 & 10 & 31.2 & 68.8 & 6.88 & 0.08 & 99.9 & 9.99 \\
\hline 2 & 7 & 0.5 & 20 & 31.1 & 68.9 & 6.89 & 0.91 & 99.1 & 9.91 \\
\hline 3 & 9 & 0.5 & 50 & 34.3 & 65.7 & 6.57 & 1.98 & 98.1 & 9.80 \\
\hline
\end{tabular}

in alkaline medium of $\mathrm{pH}$ 9. Increase in adsorption by Peshawar Al-PILC is observed with increase in $\mathrm{pH}$ range of 5-7.

Effect on adsorption of $\mathrm{Cr}$ (III) by varying $\mathrm{pH}$ of solution for raw Samwal clay and its Al-PILC forms are shown in Table 7. Raw Samwal clay shows low adsorption results for $\mathrm{Cr}$ (III) especially in alkaline conditions (65.7\% at $\mathrm{pH} 9$ ). Maximum adsorption of $68.9 \%$ is observed at neutral $\mathrm{pH}$. The Al-PILC variant shows considerably better results at all $\mathrm{pH}$ conditions with the acidic medium being the most suitable (removal of $99.9 \%$ of $\mathrm{Cr}$ (III) in solution). The least favourable is alkaline medium showing a percentage adsorption of 98.1\%.

Comparable patterns of effect of $\mathrm{pH}$ on adsorption of Cr (III) are observed for both Samwal and Peshawar Al-PILC. Maximum adsorption of chromium metal takes place between slightly acidic to neutral $\mathrm{pH}$ conditions of solution. Above $\mathrm{pH}$ value of $7, \mathrm{Cr}$ (III) precipitates as $\mathrm{Cr}(\mathrm{OH})_{3}$ and uptake of metal ions significantly decreases [35]. Similar trends of adsorption by change in $\mathrm{pH}$ of solution have been noted in previous studies conducted by researchers for $\mathrm{Cr}$ (III) $[36,37]$ as well as for other metals such as $\mathrm{Pb}$ (II), $\mathrm{Cd}$ (II), $\mathrm{Cu}$ (II), and Co (II) [38, 39].

Graphical representation of results for adsorption of $\mathrm{Cr}$ (III) by varying $\mathrm{pH}$ of solution by raw and AlPILC variants of both Peshawar and Samwal are shown in Fig. 9.

\section{Effect on Adsorption by Varying Temperature of Solution}

Table 8 shows the effect on adsorption of $\mathrm{Cr}$ (III) by varying temperature of solution for raw and Al-PILC samples of Peshawar clay. Complete adsorption 

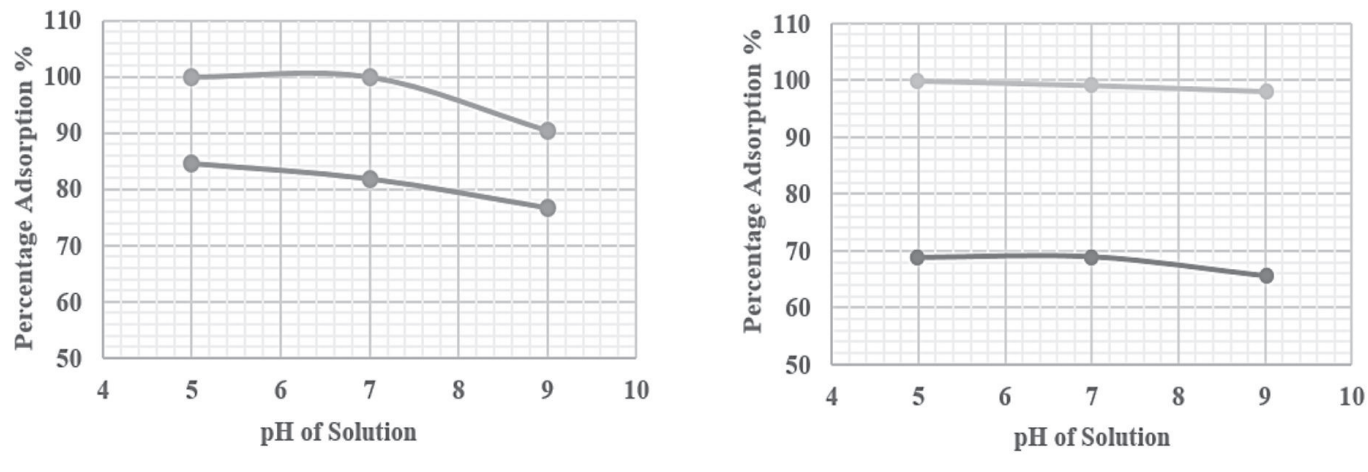

$\longrightarrow$ Peshawar - Raw Clay $\longrightarrow$ Peshawar-Al-PILC

$\longrightarrow$ Samwal - Raw Clay $\longrightarrow$ Samwal - Al-PILC

Fig. 9. Effect on Adsorption of Cr (III) by varying pH of solution: Peshawar Raw \& Al-PILC and Samwal Raw \& Al-PILC.

Table 8. Effect on Adsorption of Cr (III) by varying pH of solution: Peshawar Raw and Al-PILC.

\begin{tabular}{|c|c|c|c|c|c|c|c|c|c|}
\hline & & & \multicolumn{3}{|c|}{ PESHAWAR - RAW } & \multicolumn{3}{|c|}{ PESHAWAR Al-PILC } \\
\cline { 5 - 10 } $\begin{array}{c}\mathrm{Sr} \\
\text { No. }\end{array}$ & $\begin{array}{c}\text { Temp } \\
/{ }^{\circ} \mathrm{C}\end{array}$ & $\begin{array}{c}\text { Weight of } \\
\text { adsorbent } \\
/ \mathrm{g}\end{array}$ & $\begin{array}{c}\text { Initial } \\
\text { concentration } \\
/ \mathrm{PPM}\end{array}$ & $\begin{array}{c}\text { Final } \\
\text { concentration } \\
/ \mathrm{PPM}\end{array}$ & $\begin{array}{c}\text { Percentage } \\
\text { adsorption } \\
/ \%\end{array}$ & $\begin{array}{c}\text { Amount of } \\
\text { metal adsorbed } \\
/ \mathrm{mg} / \mathrm{g}\end{array}$ & $\begin{array}{c}\text { Final } \\
\text { concentration } \\
/ \mathrm{PPM}\end{array}$ & $\begin{array}{c}\text { Percentage } \\
\text { adsorption } \\
/ \%\end{array}$ & $\begin{array}{c}\text { Amount } \\
\text { of metal } \\
\text { adsorbed } \\
/ \mathrm{mg} / \mathrm{g}\end{array}$ \\
\hline 1 & 35 & 0.5 & 10 & 19.3 & 80.7 & 8.07 & 0 & 100 & 10.0 \\
\hline 2 & 55 & 0.5 & 20 & 17.4 & 82.6 & 8.26 & 0 & 100 & 10.0 \\
\hline 3 & 75 & 0.5 & 50 & 18.9 & 81.1 & 8.11 & 0 & 100 & 10.0 \\
\hline
\end{tabular}

Table 9. Effect on Adsorption of Cr (III) by varying $\mathrm{pH}$ of solution: Samwal Raw and Al-PILC.

\begin{tabular}{|c|c|c|c|c|c|c|c|c|c|}
\hline & & & & \multicolumn{3}{|c|}{ SAMWAL -RAW } & \multicolumn{3}{|c|}{ SAMWAL Al-PILC } \\
\cline { 5 - 11 } $\begin{array}{c}\text { Sr } \\
\text { No. }\end{array}$ & $\begin{array}{c}\text { Temp } \\
/{ }^{\circ} \mathrm{C}\end{array}$ & $\begin{array}{c}\text { Weight of } \\
\text { adsorbent } \\
/ \mathrm{g}\end{array}$ & $\begin{array}{c}\text { Initial } \\
\text { aoncentration } \\
/ \mathrm{PPM}\end{array}$ & $\begin{array}{c}\text { Final } \\
\text { concentration } \\
/ \mathrm{PPM}\end{array}$ & $\begin{array}{c}\text { Percentage } \\
\text { adsorption } \\
/ \%\end{array}$ & $\begin{array}{c}\text { Amount of } \\
\text { metal adsorbed } \\
/ \mathrm{mg} / \mathrm{g}\end{array}$ & $\begin{array}{c}\text { Final } \\
\text { concentration } \\
/ \mathrm{PPM}\end{array}$ & $\begin{array}{c}\text { Percentage } \\
\text { adsorption } \\
/ \%\end{array}$ & $\begin{array}{c}\text { Amount } \\
\text { of metal } \\
\text { adsorbed } \\
/ \mathrm{mg} / \mathrm{g}\end{array}$ \\
\hline 1 & 35 & 0.5 & 10 & 34.2 & 65.8 & 6.58 & 0.98 & 99.0 & 9.90 \\
\hline 2 & 55 & 0.5 & 20 & 30.4 & 69.6 & 6.96 & 0.77 & 99.2 & 9.90 \\
\hline 3 & 75 & 0.5 & 50 & 31.1 & 68.9 & 6.89 & 0.96 & 99.0 & 9.90 \\
\hline
\end{tabular}
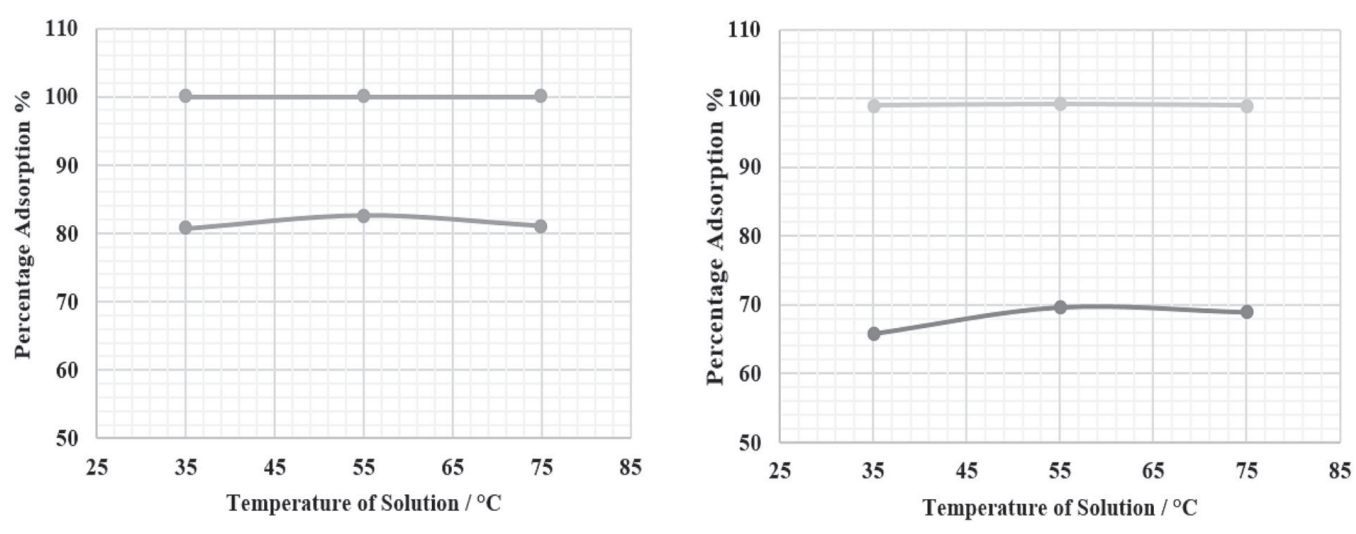

Fig. 10. Effect on Adsorption of Cr (III) by varying Temperature of solution: Peshawar Raw \& Al-PILC and Samwal Raw \& Al-PILC. 
of $\mathrm{Cr}$ (III) takes place by Peshawar Al-PILC at all temperature conditions. This shows remarkably high efficiency of pillared variant of Peshawar clay over its raw form which adsorbs only a maximum of $82.6 \%$ of $\mathrm{Cr}$ (III) at $55^{\circ} \mathrm{C}$.

The effect on adsorption of $\mathrm{Cr}$ (III) by varying temperature of solution for Samwal raw and Al-PILC is shown in Table 9. Almost $99 \%$ of $\mathrm{Cr}$ (III) are removed in solution by Samwal Al-PILC. Moderately high temperature $\left(55{ }^{\circ} \mathrm{C}\right)$ is optimum in this experiment as a maximum of $99.2 \%$ of $\mathrm{Cr}$ (III) is adsorbed by Samwal Al-PILC. However, adsorption regresses to $99 \%$ with an increase of $20^{\circ} \mathrm{C}$.

The comparative graphical illustration of results for effect of varying temperature of solution on adsorption of Cr (III) by both Peshawar and Samwal's raw clays and Al-PILC variants are shown in Fig. 10.

\section{Conclusion}

Al-PILC prepared from bentonite clay can be effectively used for adsorption and removal of $\mathrm{Cr}$ (III) at variable $\mathrm{pH}$ and temperature conditions. Bentonite clay is abundantly available in Pakistan. Clays sourced from Peshawar and Samwal regions can be chemically modified into Al-PILC by efficient, hassle free and low cost pillaring treatment method. The pillaring process enhances the cationic exchange capacity and surface area of bentonite clay; making it an excellent adsorbent for elimination of $\mathrm{Cr}$ (III) in industrial wastewaters. This can help to provide an affordable and efficient solution for environmental hazards associated with chromium pollution generated from effluents discharged from leather industries in Pakistan.

\section{Acknowledgements}

This research was carried out as a part of research and development program of University of the Punjab, Lahore, in collaboration with Pakistan Council of Scientific and Industrial Research Laboratories Complex, Lahore (PCSIR), Pakistan.

\section{Conflict of Interest}

The authors declare no conflict of interest.

\section{References}

1. MEHMOOD A., MAHMOOD A., MUSSTJAB S. A., EQANIB A.S., ISHTIAQ M., ASHRAF A., BIBI N., QADIRE A., LIF J., ZHANG G. A review on emerging persistent organic pollutants: Current scenario in Pakistan. Hum. Ecol. Risk. Assess. 23, 1, 2017.

2. MAHMOOD Q., SHAHEEN S., BILAL M., TARIQ M., ZEB B.S., ULLAH Z., ALI A. Chemical pollutants from an industrial estate in Pakistan: a threat to environmental sustainability. Appl. Water. Sci 9, 47, 2019.

3. FU F., WANG Q. Removal of Heavy Metal Ions from Wastewaters: A Review. J. Environ. Manage. 92, 407, 2011.

4. KHAN S.A, IBRAHIM M., JAMIL Y., AMIN N., ULLAH S., ABBAS F. Chromium quantification in a leather tanning industrial area using laser induced breakdown spectroscopy. Pol. J. Environ. Stud. 23 (6), 2333, 2014.

5. OMM-E-HANY, ASIA N., AAMIR A., HUMAIRA K. Determination of Chromium in the Tannery wastewater, Korangi, Karachi. Int. J. Environ. Sci. Nat. Res. 15 (4), 2018.

6. CHOWDHURY M., MOSTAFA M.G., BISWAS T.K., MANDAL A., SAHA A.K. Characterization of the Effluents from Leather Processing Industries. Environ. Process. 2, 173, 2015.

7. DARGO H., AYALEW A. Tannery waste water treatment: a review. Int. J. Emerg. Trends Sci. Technol. 1, (9), 1488, 2014.

8. GHAFOOR A., ASLAM M., RASOOL S. Determinants of leather goods exports: A case of Pakistan. J. Bus. Econ. 4, 256, 2012.

9. SIDDIQUI A., UROOS A., NADEEM F. Sectoral competitiveness and value chain analysis: leather Gloves value chain analysis in Pakistan. TDAP. 2016.

10. HASHMI G.J., DASTAGEER G., SAJID M.S., ALI Z., MALIK M.F., LIAQAT I. Leather Industry and Environment: Pakistan Scenario. Int. J. Appl. Biol. Forensic. 1 (2), 20, 2017.

11. JUNAID M., HASHMI M.Z., TANG Y.M., MALIK R., PEI D.S. Potential health risk of heavy metals in the leather manufacturing industries in Sialkot, Pakistan. Sci. Rep. 7, 8848, 2017.

12. MISHRA S., BHARAGAVA R.M. Toxic and genotoxic effects of hexavalent chromium in environment and its bioremediation strategies. J. Environ. Sci. Health. C. 34, 1, 2016.

13. MASHI S.A., ALHASSAN M.M. Effects of Wastewater Discharge on Heavy Metals Pollution in Fadama Soils in Kano City, Nigeria. Biomed. Environ. Sci. 20, 70, 2007.

14. WANG G., HUA Y., SU X., KOMARNENI S., MA S., AND WANG Y. Cr (VI) adsorption by montmorillonite nanocomposites. Appl. Clay Sci. 125, 111, 2016.

15. PARK Y., AYOKO G.A., HORVATH E., KURDI R., KRISTOF J., FROST R.L. Structural characterisation and environmental application of organoclays for the removal of phenolic compounds. J. Colloid. Interface. Sci. 393, 319, 2013.

16. SWARNALATHA K., AYOOB S. Adsorption studies on coir pith for heavy metal removal. I. J. S. Eng. 9, 259, 2016.

17. GUNATILAKE S.K. Methods of Removing Heavy Metals from Industrial Wastewater. J. Multidiscip. Eng. Sci. Studi. 1, 1, 2015

18. MISHRA S.P. Adsorption-Desorption of Heavy Metal Ions. Curr. Sci. 107, 601, 2014.

19. KUL A.R., KOYUNCU H. Adsorption of $\mathrm{Pb}$ (II) ions from aqueous solution by native and activated bentonite: Kinetic, equilibrium and thermodynamic study. J. Hazard. Mater. 179, 332, 2010.

20. ZHAO Y., YANG S., DING D., CHEN J., YANG Y., LEI Z., FENG C., ZHANG Z. Effective adsorption of Cr (VI) from aqueous solution using natural Akadama clay. J. Colloid. Interface. Sci. 395, 198, 2013. 
21. MATUSIK J., BAJDA T. Immobilization and reduction of hexavalent chromium in the interlayer space of positively charged kaolinites, J. Colloid. Interface. Sci. 398, 74, 2013.

22. LOTHENBACH B., KERBS R., FURRER G., GUPTA S.K., SCHULIN R. Immobilization of cadmium and zinc in soil by Al-montmorillonite and gravel sludge, Eur. J. Soil Sci. 49, 141, 1998.

23. SARTOR L.R., DE AZEVEDO A.C., RAMATIS G., ANDRADE P. Study of colloidal properties of natural and Al-pillared smectite and removal of copper ions from an aqueous solution. Environ. Technol. 36 (6), 786, 2015.

24. TOMUL F. Adsorption and catalytic properties of $\mathrm{Fe} / \mathrm{Cr}-$ pillared bentonites. Chem. Eng. J. 185-186, 380-390, 2012.

25. DING M., ZUOS. M., QI C. Preparation and characterization of novel composite $\mathrm{Al} / \mathrm{Cr}$-pillared clays and preliminary investigation for benzene adsorption. Appl. Clay Sci. 115, 9, 2015.

26. KHANKHASAEVA S.T., DASHINAMZHILOVA E.T., DARIMA D.V. Oxidative degradation of sulfanilamide catalyzed by $\mathrm{Fe} / \mathrm{Cu} / \mathrm{Al}$-pillared clays. Appl. Clay Sci. 146, 92, 2017

27. ZUO S., DING M., TONG J., FENG L., QI C. Study on the preparation and characterization of a titanium-pillared clay-supported $\mathrm{Cr}-\mathrm{Ce}$ catalyst and its application to the degradation of a low concentration of chlorobenzene. Appl. Clay Sci. 105, 2015.

28. AYUB M., YUSUF M., MIAN M.A., IQBAL M., RAFIQ M. Characterization of Fuller's Earth from D.G. Khan. Pak. J. Sci. Ind. Res. 32, 12, 1988.

29. SHAH S.M.I. Stratigraphy of Pakistan. GSP Memoirs. 22, 381, 2009.

30. PANSU M., JACQUES G. Handbook of Soil Analysis: Mineralogical, Organic, and Inorganic Methods, SpringerVerlag, Berlin, Heidelberg, 2006.

31. KIM S.C., LEE D.K. Preparation of Al-Cu pillared clay catalysts for the catalytic wet oxidation of reactive dyes. Catal. Today. 97, 153, 2004.
32. KARAMANIS D., ASSIMAKOPOULOS P.A. Efficiency of Aluminium-pillared montmorillonite on the removal of cesium and copper from aqueous solutions. Water. Res. 41, $1897,2007$.

33. RATHNAYAKE S.I., MARTENS W.N., XI Y., FROST R.L., AYOKO G.A. Remediation of Cr (VI) by inorganicorganic clay. J. Colloid. Interface. Sci. 490, 163, 2017.

34. OLADIPO A.A., GAZI M. Uptake of $\mathrm{Ni}^{2+}$ and Rhodamine B by Nano Hydroxyapatite/Alginate Composite Beads: Batch and Continuous-Flow Systems. Toxicol. Environ. Chem. 98 (2), 189, 2015.

35. LIU J., WU X., HU Y., DAI C., PENG Q., LIANG D. Effects of $\mathrm{Cu}$ (II) on the adsorption behaviours of $\mathrm{Cr}$ (III) and $\mathrm{Cr}$ (VI) onto kaolin. J. Chem. 11, 2016.

36. CIOPEC M., DAVIDESCU C.M., NEGREA A., MUNTEAN C., POPA A., NEGREA P., LUPA L. Equilibrium and kinetic studies of the adsorption of $\mathrm{Cr}$ (III) ions onto Amberlite XAD-8 impregnated with Di-(2-ethylhexyl) Phosphoric Acid (DEHPA). Adsorpt. Sci. Technol. 29, 989-1005, 2011.

37. ALEMU A., LEMMA B., GABBIYE N. Adsorption of chromium (III) from aqueous solution using vesicular basalt rock. Cogent. Environ. Sci. 5 (1), 1650416, 2019.

38. MOHAPATRA M., MOHAPATRA L., SINGH P., ANAND, S., MISHRA B. K. A comparative study on $\mathrm{Pb}$ (II), Cd (II), Cu (II), Co (II) adsorption from single and binary aqueous solutions on additive assisted nanostructured goethite. Int. J. Eng. Sci. Technol. 2, 89, 2010.

39. OULDM'HAMED M., KHEZAMI L., ALSHAMMARI A.G., OULD-MAME S.M., GHILOUFI I., LEMINE O.M. Removal of cadmium (II) ions from aqueous solution using $\mathrm{Ni}$ (15 wt.\%)-doped $\alpha$ - $\mathrm{Fe}_{2} \mathrm{O}_{3}$ nanocrystals: equilibrium, thermodynamic, and kinetic studies. Water. Sci. Technol. 72 (4), 608-615, 2015. 